\title{
Graphene Oxide Attenuates the Cytotoxicity and Mutagenicity of PCB 52 via Activation of Genuine Autophagy
}

Yun Liu, ${ }^{\dagger, l}$ Xinan Wang, ${ }^{\dagger, l}$ Juan Wang, ${ }^{\dagger}$ Yaguang Nie, ${ }^{\dagger}$ Hua Du, ${ }^{\dagger}$ Hui Dai, ${ }^{\dagger}$ Jingjing Wang, ${ }^{\dagger}$ Mudi Wang, ${ }^{\dagger}$ Shaopeng Chen, ${ }^{\dagger}$ Tom K. Hei, ${ }^{\ddagger}$ Zhaoxiang Deng, ${ }^{\S}$ Lijun Wu, ${ }^{\dagger}$ and $\mathrm{An} \mathrm{Xu}^{*}, \dagger$

${ }^{\dagger}$ Key Laboratory of Ion Beam Bioengineering, Hefei Institutes of Physical Science, Chinese Academy of Sciences and Anhui Province, Hefei, Anhui 230031, P. R. China

${ }^{\ddagger}$ Center for Radiological Research, Department of Radiation Oncology, College of Physicians and Surgeons, Columbia University, New York, New York 10032, United States

${ }^{\S}$ Department of Chemistry, University of Science and Technology of China, Hefei, Anhui 230026, P.

R. China

*Corresponding author:

$\mathrm{An} \mathrm{Xu}$

Key Laboratory of Ion Beam Bioengineering

Hefei Institutes of Physical Science

Chinese Academy of Sciences and Anhui Province

Hefei, Anhui, 230031, P. R. China

Tel.: +86 $55165593336 \quad$ Fax: +86 55165595670

Email: anxu@ipp.ac.cn

"These authors contributed equally to this work. 
Number of pages in SI file: 10

Number of figures in SI fie: 8 
A

\begin{tabular}{ccc}
\hline Graphene Oxide & Hydrodynamic Size $($ HDS, $\mathbf{n m}) /$ PDI & Zeta Potential $(\mathbf{Z p}, \mathbf{m V})$ \\
\hline In water & $253.10 \pm 10.78 / 0.31 \pm 0.07$ & $-46.00 \pm 1.08$ \\
\hline In culture medium & $1342.00 \pm 153.70 / 0.65 \pm 0.18$ & $-10.55 \pm 0.54$ \\
\hline
\end{tabular}

B

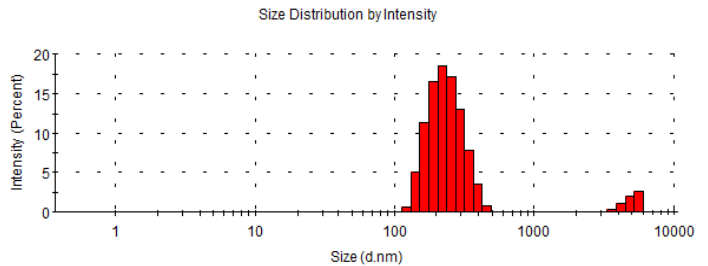

C

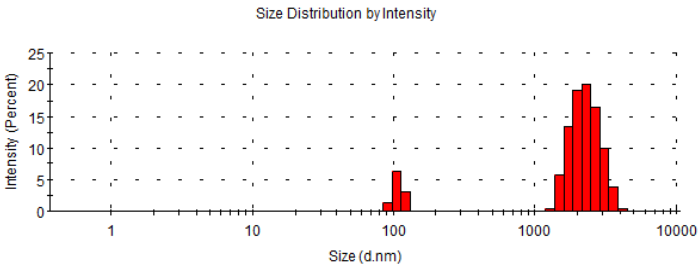

D

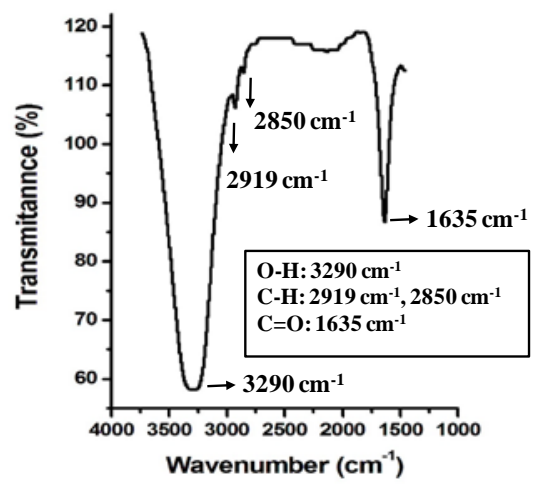

Figure S1. (A) Dynamic light scattering (DLS) and Zeta potential of GO in water and culture medium. DLS spectra of GO dispersions in water (B) and culture medium (C). GO stock suspension was diluted to the concentration of $100 \mu \mathrm{g} / \mathrm{mL}$. PdI = Polydispersity index. (D) FTIR spectrum of GO nanosheets (range: 4000-1000 $\left.\mathrm{cm}^{-1}\right)$. 
A

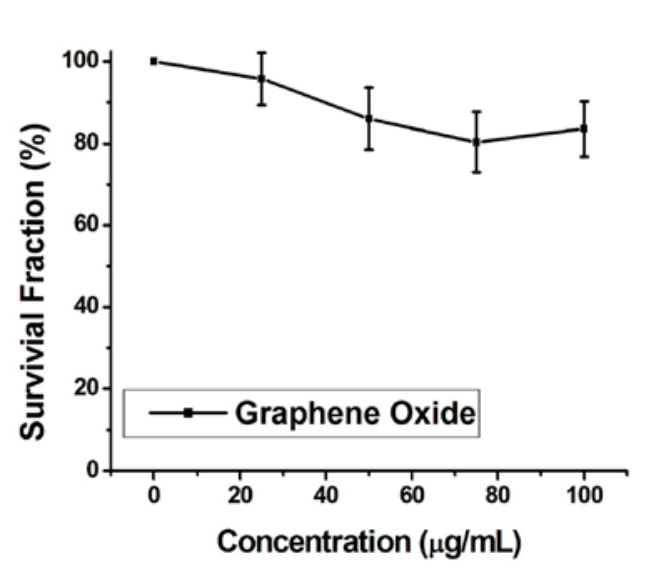

B

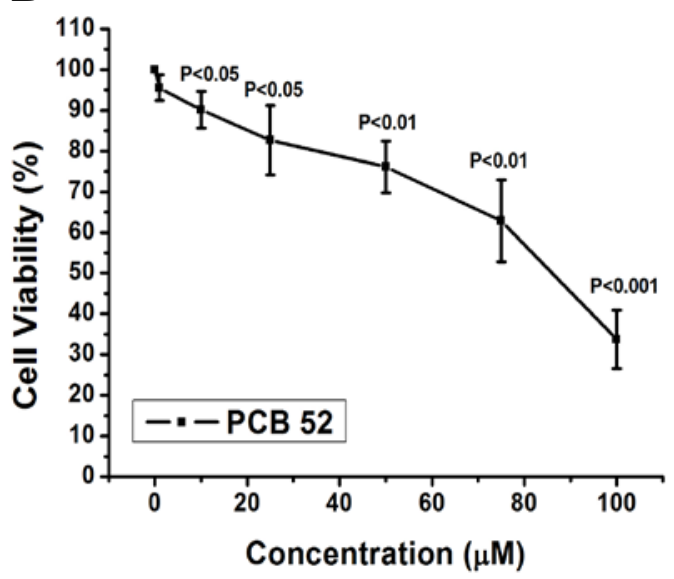

Figure S2. Cytotoxicity of GO and PCB 52. (A) $A_{L}$ cells were exposed to graded doses of GO for $24 \mathrm{~h}$, and the cytotoxicity was detected by colony formation assay. (B) $A_{L}$ cells were exposed to increasing doses of PCB 52 for $24 \mathrm{~h}$, and the cytotoxicity was detected by alamar blue assay. (The results are the mean values of triplicates from a representative of three experiments. Mean \pm S.D., $n=3$ ). 

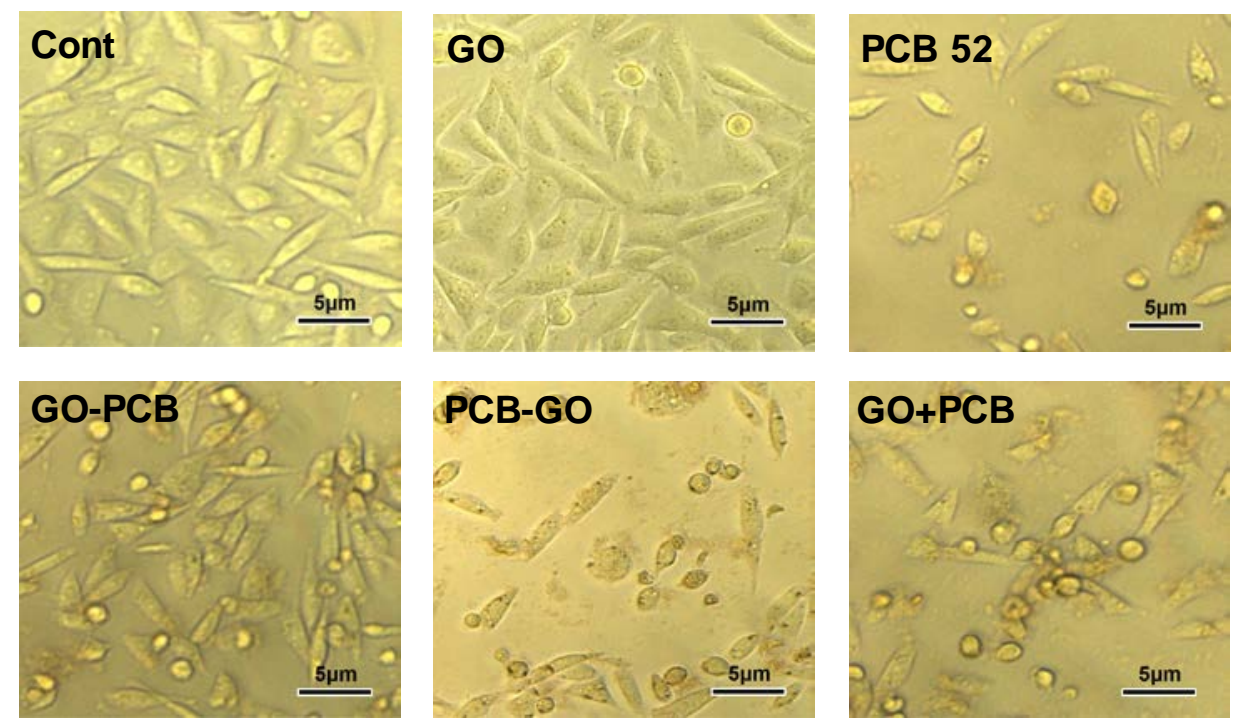

Figure S3. Representative morphology of cells treated by GO, PCB 52 and different manners of co-exposure. GO-PCB: Cells were pre-treated with $10 \mu \mathrm{g} / \mathrm{mL}$ GO for $4 \mathrm{~h}$, followed by addition of $100 \mu \mathrm{M}$ PCB 52 for another 24 h. PCB-GO: Cells were pre-treated with $100 \mu \mathrm{M}$ PCB 52 for $4 \mathrm{~h}$, followed by adding with $10 \mu \mathrm{g} / \mathrm{mL}$ GO for another 24 h. GO+PCB: Cells were exposed to $10 \mu \mathrm{g} / \mathrm{mL}$ GO and $100 \mu \mathrm{M}$ PCB 52 for $24 \mathrm{~h}$. 

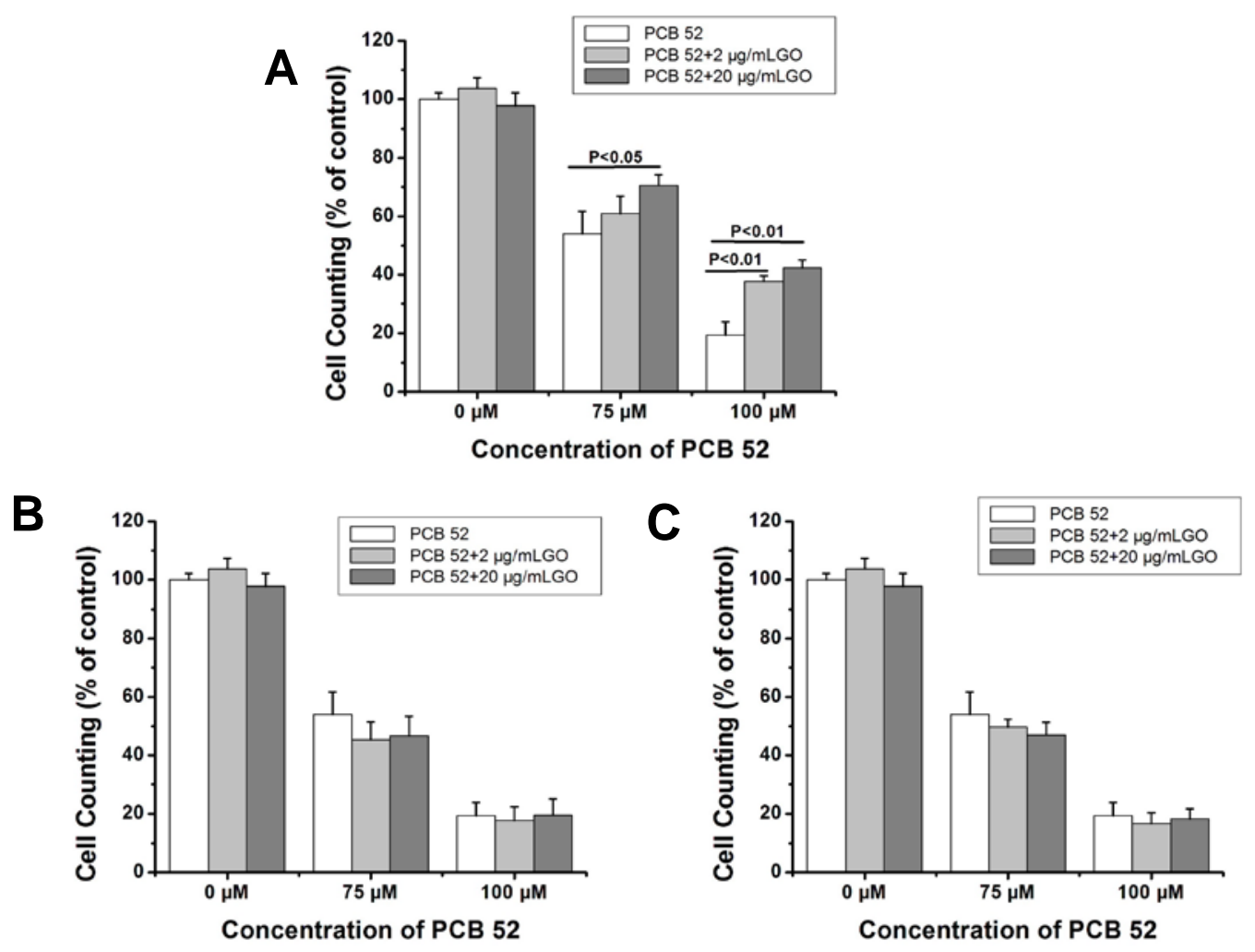

Figure S4. Combined cytotoxicity of GO and PCB 52 by cell counting assay. (A) Cells were pre-treated with GO ( $2 \mu \mathrm{g} / \mathrm{mL}, 20 \mu \mathrm{g} / \mathrm{mL})$ for $4 \mathrm{~h}$, followed by exposing to PCB $52(75 \mu \mathrm{M}, 100 \mu \mathrm{M})$ for another $24 \mathrm{~h}$. (B) Cells were pre-treated with PCB $52(75 \mu \mathrm{M}, 100 \mu \mathrm{M})$ for $4 \mathrm{~h}$, followed by exposing to $\mathrm{GO}(2 \mu \mathrm{g} / \mathrm{mL}, 20 \mu \mathrm{g} / \mathrm{mL})$ for another 24 h. (C) Cells were exposed to GO (2 $\mu \mathrm{g} / \mathrm{mL}, 20 \mu \mathrm{g} / \mathrm{mL})$ and PCB 52 (75 $\mu \mathrm{M}, 100 \mu \mathrm{M}$ ) simultaneously for $24 \mathrm{~h}$. (The results are the mean values of triplicates from a representative of three experiments. Mean \pm S.D., $n=3$ ). 

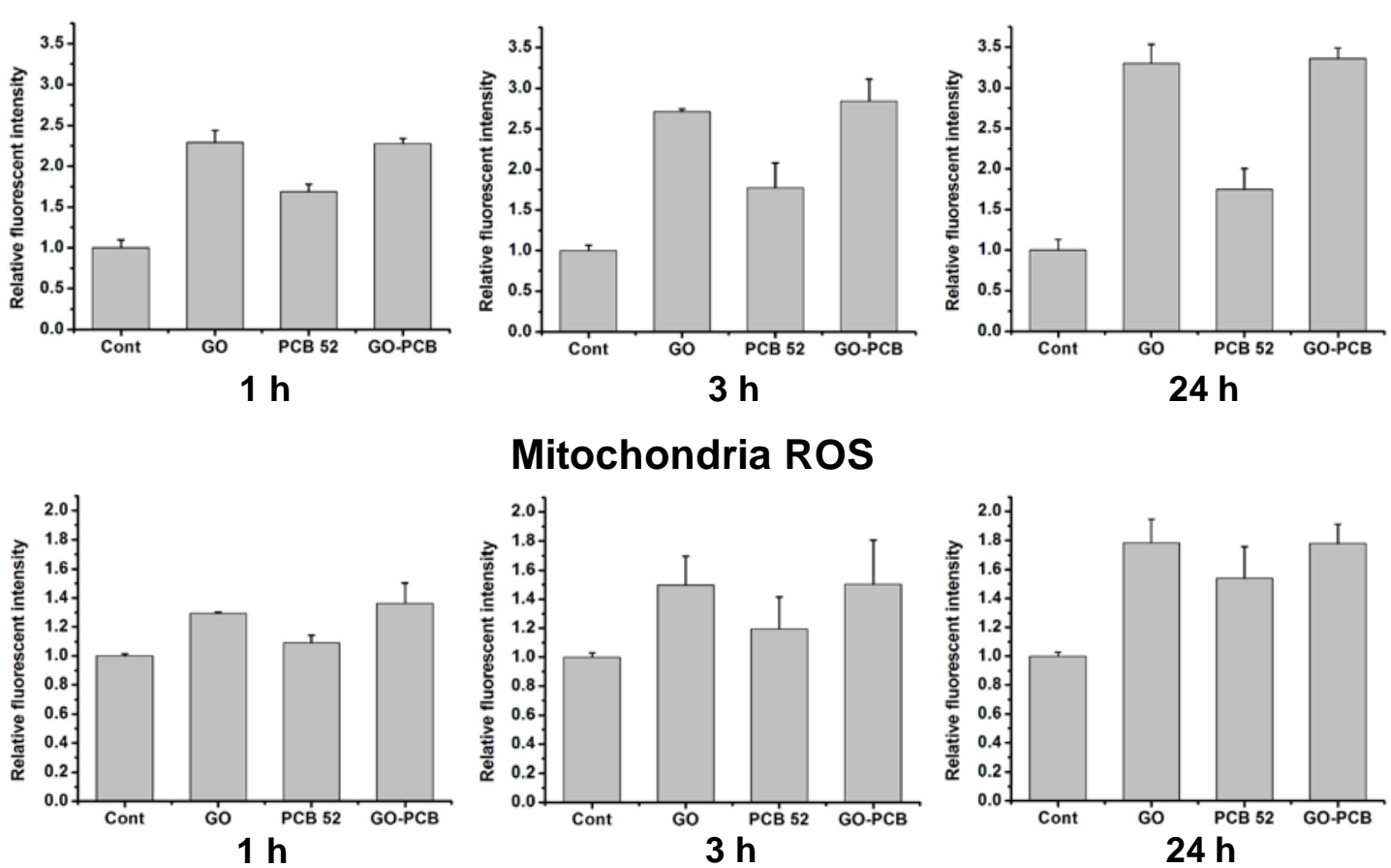

Mitochondria ROS

Figure S5. Oxidative stress induced by GO, PCB 52 and co-exposure. Intracellular ROS (A, B, C) and Mitochondrial Superoxide (D, E, F) production were quantified by DCF-DA and MitoSox fluorescence. GO-PCB: Cells were pre-treated with 10 $\mu \mathrm{g} / \mathrm{mL}$ GO for $4 \mathrm{~h}$, followed by addition of $50 \mu \mathrm{M}$ PCB 52 for another $1 \mathrm{~h}(\mathrm{~A}, \mathrm{D}), 3$ h (B, E) and 24 h (C, F). GO and PCB 52 single treatment was added at the same time with GO and PCB 52 in the co-exposure. (The results are the mean values of triplicates from a representative of three experiments. Mean \pm S.D., $n=3$ ). 

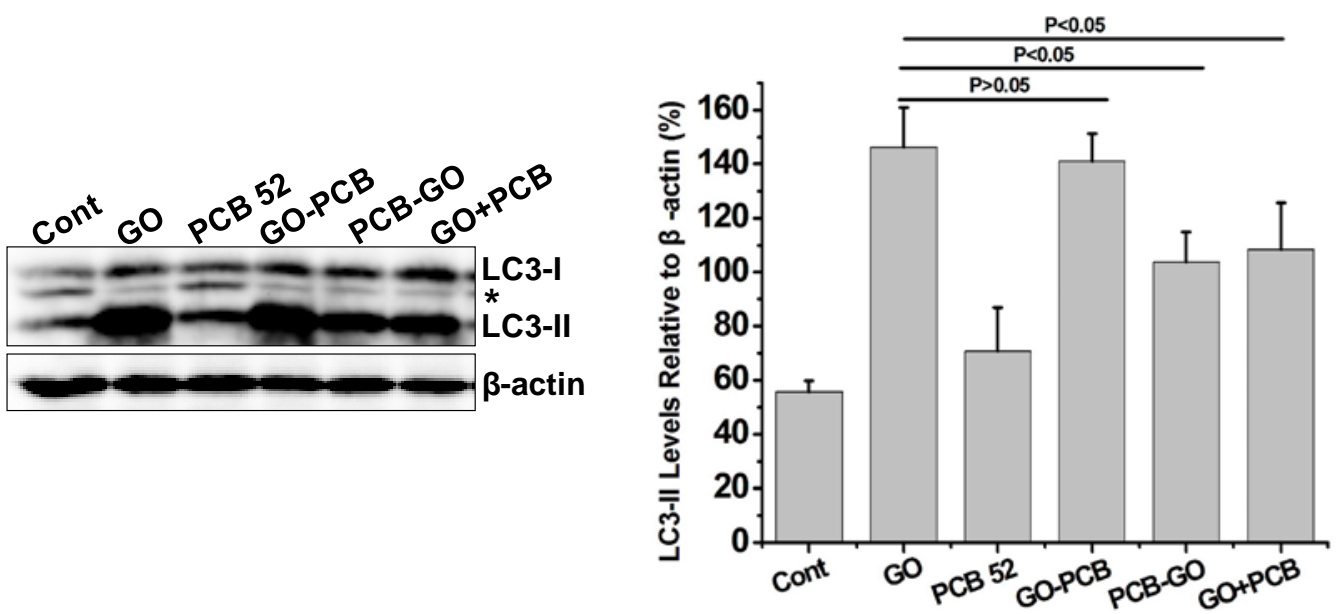

Figure S6. Combined autophagic effect caused by GO and PCB 52. GO-PCB: Cells were pre-treated with $10 \mu \mathrm{g} / \mathrm{mL}$ GO for 4 h, followed by adding with $75 \mu \mathrm{M}$ PCB 52 for another 24 h. PCB-GO: Cells were pre-treated with $75 \mu \mathrm{M}$ PCB 52 for $4 \mathrm{~h}$, followed by adding with $10 \mu \mathrm{g} / \mathrm{mL}$ GO for another $24 \mathrm{~h}$. GO+PCB: Cells were exposed to $10 \mu \mathrm{g} / \mathrm{mL}$ GO and $75 \mu \mathrm{M}$ PCB 52 for $24 \mathrm{~h}$. (*indicates non-specific bands. LC3-II levels were quantified by densitometric analysis relative to $\beta$-actin. Mean \pm S.D., $n=3)$. 
A

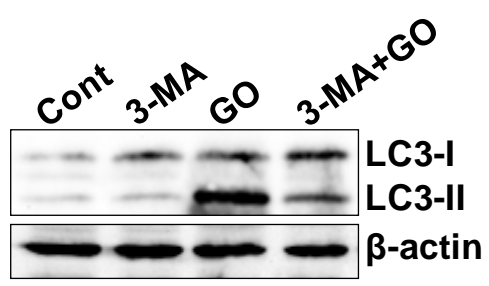

C

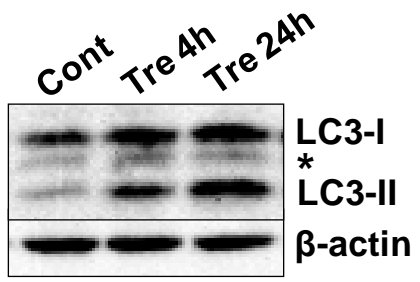

B

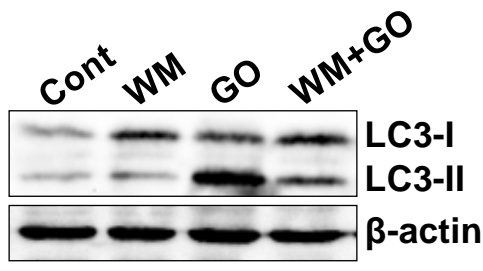

D

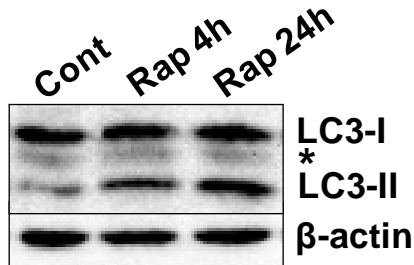

Figure S7. LC3 conversion induced by $10 \mu \mathrm{g} / \mathrm{mL}$ GO could be inhibited by $2.5 \mathrm{mM}$ 3-MA (A) or $500 \mathrm{nM}$ wortmannin (WM) (B). LC3 conversion induced by $100 \mathrm{mM}$ trehalose (Tre) (C) or $200 \mathrm{nM}$ rapamycin (Rap) (D). (* indicates non-specific bands.) 
A

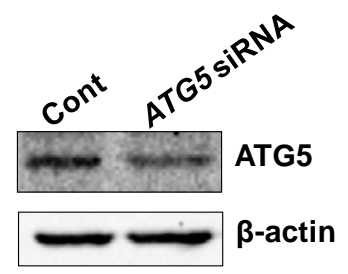

B

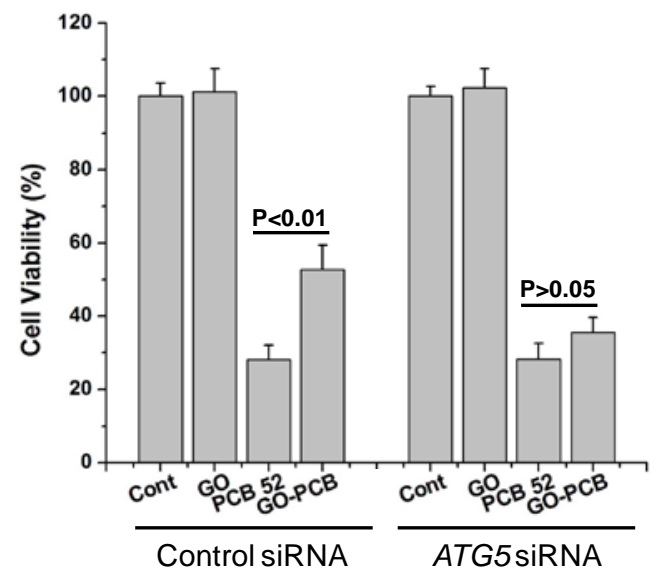

Figure S8. (A) Western blotting of Atg5 in $A_{L}$ cells transfected with control siRNA or Atg5 siRNA for $48 \mathrm{~h}$. (B) Cell viability assay of $A_{L}$ cells treated with $10 \mu \mathrm{g} / \mathrm{mL}$ GO, $100 \mu \mathrm{M}$ PCB 52 or GO-PCB (100 $\mu \mathrm{M}$ PCB 52 pre-treated with $10 \mu \mathrm{g} / \mathrm{mL}$ GO) after transfection with control siRNA or Atg5 siRNA for $48 \mathrm{~h}$. (The results are the mean values of triplicates from a representative of three experiments. Mean \pm S.D., $\mathrm{n}$ $=3)$. 